International Journal of Advanced Chemistry, 2(2)(2014) 109-116
International Journal of Advanced Chemistry
Journal home page: $\begin{gathered}\text { www.sciencepubco.com/index.php/IJAC } \\ \text { doi: } 10.14419 / \text { ijac.v2i2.3054 } \\ \text { Research Paper }\end{gathered}$

\title{
Determination of doxazosin in different matrices: a review
}

\author{
Alankar Shrivastava ${ }^{1 *}$, Manali Jain ${ }^{2}$, Rakhee Varshneya ${ }^{2}$ \\ ${ }^{I}$ Associate Professor, Department of Pharmacy, Institute of Biomedical Education and Research Mangalayatan University Beswan, \\ Aligarh, 202146 U.P, INDIA \\ ${ }^{2}$ Department of Biotechnology, Institute of Biomedical Education and Research Mangalayatan University Beswan, \\ Aligarh, 202146 U.P, INDIA \\ *Corresponding author E-mail: alankar.shrivastava@mangalayatan.edu.in
}

\begin{abstract}
Doxazosin mesylate is used in the management of hypertension and benign prostatic hyperplasia. It is one of the important alpha one adrenoreceptor blocker. Alpha one adrenoreceptor blockers are most preferred therapy for symptomatic relief of benign prostatic hyperplasia. In this review analytical methods for the determination of doxazosin in different matrices are discussed. Analytical methods are classified in to spectrophotometry, chromatography and electroanalytical methods. This literature is also focused on advantages, disadvantages of different analytical methods. This review article is an attempt to provide information to the scientists engaged in research related to doxazosin.
\end{abstract}

Keywords: Benign Prostatic Hyperplasia, Doxazosin Mesylate, Analytical Methods, Spectrophotometry, Chromatography, Electro analytical Methods.

\section{Introduction}

The prostate is a walnut-sized gland that forms part of the male reproductive system. The gland is made of two lobes, or regions, enclosed by an outer layer of tissue. The prostate is located in front of the rectum and just below the bladder, where urine is stored. The prostate also surrounds the urethra, the canal through which urine passes out of the body (U.S. Department of Health and Human Services, 2006).

The prostate's job is to make some of the fluid that protects and nourishes sperm cells in semen, making the semen more liquid. Just behind the prostate are glands called seminal vesicles that make most of the fluid for semen. The urethra, which is the tube that carries urine and semen out of the body through the penis, goes through the center of the prostate. The prostate starts to develop before birth. It grows rapidly during puberty, fueled by male hormones (called androgens) in the body. The main androgen, testosterone, is made in the testicles (American Cancer Society, 2014).

The prostate gland is an exocrine gland found in all mammals. It secretes enzymes, amines, lipids and metal ions, essential for the normal function of the spermatozoa. Accumulation and secretion of extraordinarily high levels of citrate is one of the principal functions of the prostate gland of humans and other animals (Kindblom 2013).

The human prostate gland is one of the only internal organs that continue to enlarge throughout adulthood. The specific mechanisms that regulate this growth, as well as the pathological changes leading to the phenotype observed in the disease benign prostatic hyperplasia (BPH), are essentially unknown (Schauer \& Rowley, 2011).

The human prostate is subject to a variety of pathologic conditions and syndromes that are not well understood. The prevalence of benign prostatic hyperplasia (BPH) and chronic prostatitis /chronic pelvic pain syndrome (CP/CPPS) greatly exceeds that of prostate cancer, which is the most common non-cutaneous malignancy among males in the United States. Patients suffering from benign prostatic symptoms report a substantially reduced quality of life, and the relationship between benign prostate conditions and prostate cancer is uncertain (Freeman \& Solomon, 2011).

Benign Prostatic Hyperplasia (BPH) is a progressive disease that is commonly associated with bothersome lower urinary tract symptoms (LUTS) such as frequent urination, urgency, nocturia, decreased and intermittent force of stream, and the sensation of incomplete bladder emptying. The term BPH actually refers to a histologic condition, namely the presence of stromal glandular hyperplasia within the prostate gland (Shrivastava \& Gupta, 2012). Benign prostatic hyperplasia (BPH) affects over 50 percent of men by age 60 and is the cause of millions of dollars of healthcare expenditure for treatment of lower urinary tract symptoms (LUTS) and urinary obstruction (Bechis et al., 2014).

The condition known as benign prostatic hyperplasia may be defined as a benign enlargement of the prostate gland resulting from a proliferation of both benign epithelial and stromal elements. It might also be defined clinically as a constellation of lower urinary tracts symptoms (LUTSs) in aging men (McLaren et al., 2011).

$\alpha_{1}$-Adrenoceptors are present in the prostate, urethra, bladder, ureter, vas deferens, peripheral ganglia, nerve terminals, vascular tissues, and central nervous system (CNS), and could potentially influence overall urinary function and contribute to both the therapeutic and adverse effects of $\alpha_{1}$-adreceptor antagonists (Yamada and Ito, 2011). The $\alpha_{1}$-blockers reduce smooth muscle tone in the prostate and result in rapid improvements in urinary symptoms and flow (Irani 2006, Shrivastava 2013).

Alpha-1 blockers are the first option for the medical treatment of LUTS caused by BPH (Takahashi 2011). Alpha 1-adrenoceptor antagonists ( $\alpha$-blockers) remain the most widely used pharmacologic agents for treating bladder outflow resistance caused by BPH (Perabo 2012, Shrivastava 2013). The amount of prescriptions for $\alpha$ - blockers has been increasing steadily in the last 10 years (Ding

Copyright $\odot 2014$ Alankar Shrivastava et al. This is an open access article distributed under the Creative Commons Attribution License, which permits unrestricted use, distribution, and reproduction in any medium, provided the original work is properly cited. 
2013, Shrivastava \& Aggrawal 2013). Currently, five $\alpha$-blockers are used: alfuzosin, doxazosin, sildosin, tamsulosin, terazosin (Shrivastava 2014)

Doxazosin mesilate (Fig. 1) is an alpha1-adrenoceptor blocker with actions and uses similar to those of prazosin, but a longer duration of action. It is used in the management of hypertension and in benign prostatic hyperplasia to relieve symptoms of urinary obstruction (Attia et al., 2012). Doxazosin was initially developed as antihypertensive, is a selective alpha one adrenoreceptor blocker (Os \& Stokke, 1999). Doxazosin should be initially given at a dose of $1 \mathrm{mg} / \mathrm{d}$ and titrated over a period of 1-2 weeks to a maximum dose of $8 \mathrm{mg} / \mathrm{d}$. Titration reduces risk of first dose cardiovascular side effects (Chou 2007).

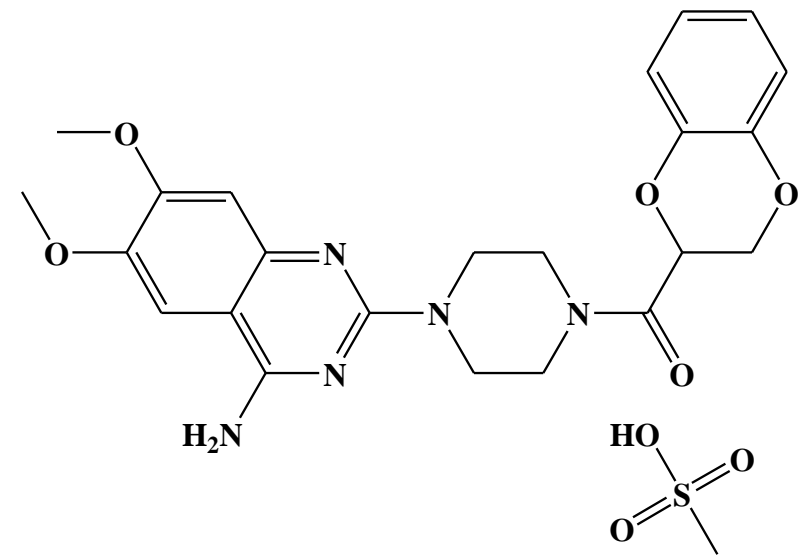

Fig. 1: Molecular Structure of Doxazosin Mesylate

Recent pilot study suggests the potential efficacy of doxazosin when rapidly titrated in reducing cocaine use (Shorter et al., 2013). Another recent study recommended use of doxazosin to render children stone free within a shorter period, which would inevitably diminish the number of colic attacks and the need for analgesic usage (Erturhan et al., 2013).

Combined doxazosin and finasteride therapy improved LUTS and reduced the risk of overall clinical progression of BPH compared to each drug separately in men followed over 4 years (Wilt \& MacDonald 2006).

Doxazosine [4-(4-amino-6, 7-dimethoxyquinazolin-2-yl) piperazin-1-yl]-(2, 3-dihydro-1,4-benzodioxin-2-yl)methanone (Eu $\mathrm{Ph} 2007)$ is a quinazoline compound of the methanesulphonate family; peak plasma concentration is achieved within 2 to 3 hours of ingestion, with a bioavailability of $65 \%$ (Thiyagarajan 2002, Shrivastava \& Gupta 2011). Other names are Cardura, Doxasin, Doxazosin Mesilate and UK-33274-27. Its molecular formula is $\mathrm{C}_{23} \mathrm{H}_{25} \mathrm{~N}_{5} \mathrm{O}_{5} \cdot \mathrm{CH}_{3} \mathrm{SO}_{3} \mathrm{H}$, with a molecular weight of 547.6 and a CAS number of 77883-43-3. Doxazosin mesylate is white or almost white crystalline powder slightly soluble in water and methanol and soluble in a mixture of 15 parts of water and 35 parts of tetrahydrofuran. It is practically insoluble in acetone (Xu \& Madden 2011).

Terazosin and doxazosin have a very similar plasma clearance (1$1.2 \mathrm{ml} / \mathrm{min} / \mathrm{kg}$ ) and volume of distribution $(0.88-0.97 \mathrm{l} / \mathrm{kg})$. Although doxazosin is found to have a longer half-life than prazosin, the benzodioxan moiety may not be as water-soluble as the tetrahydrofuran group in terazosin. Metabolism of doxazosin in man is similar to prazosin; although have altered pharmacokinetics, primarily handled by the liver and the metabolites are, as prazosin, 6- or 7- demethylations or, to a small extent, production of piperazine and diaminoquinazoline compounds Doxazosin also produces hydroxylated benzodioxan metabolites and less than $15 \%$ of doxazosin survives unaltered (Humphreys \& Waite 1989).

Guideline for male lower urinary tract symptoms published by Japanese Society of Neurogenic Bladder describes effectiveness of doxazosin therapy in combination with finasteride causing significantly decrease in the risk of acute urinary retention and surgical intervention (Homma et al., 2009). Another report is of medical treatment of distal ureteral calculi with doxazosin resulted in a significantly increased stone-expulsion rate and decreased expulsion time (Gurbuz et al., 2011).

On the basis of above explanations it can be stated that doxazosin is important alpha one adrenoreceptor blocker. Thus there is clear need for discussion on different analytical methods for the determination of doxazosin in different matrices. This review will help scientists and researchers engaged in developing different analytical method or formulation of doxazosin. This review is divided into three different parts; spectrophotometry, chromatography and electroanalytical methods.

\section{Analytical methods}

All of the analytical methods found in literature survey are categorized into three different parts and are presented here in Table 1,2 and 3 , includes summary of all of the spectrophotometry, chromatography and electroanalytical methods respectively.

Analytical method development and validation procedures are vital in the discovery and development of drugs and pharmaceuticals (Chandran \& Singh 2007, Shrivastava \& Gupta 2011). The word validation originates from the Latin validus meaning strong, and suggests that something has been proved to be true, useful and of an acceptable standard (Araujo 2009, Kumar et al., 2012, Shrivastava \& Saxena, 2014). Thus we have included discussion of important validation parameters such as Linearity range, LOD and LOQ in this review.

\subsection{Spectrophotometry method}

Spectrophotometry methods are among the oldest methods of analytical chemistry. Spectrophotometry as a measuring technique has developed enormously as a consequence of the progress in the technology, and in the development of the new materials and of methods of data processing. Spectrophotometric methods of identification and determination of substances are based on the existence of relationship between the position and the intensity of absorption bands of electromagnetic radiations, on the one hand, and the molecular structure on the other (Marczenko \& Balcerzak 2000).

In our literature survey fourteen different spectrophotometry methods for the determination of doxazosin were found. Two fluorimetry methods (Ayad et al., 2012, Ammar et al., 2014) are also available. Specrofluorimetry as an analytical tool provides a well-defined identity of the compounds present in the sample on the basis of their unique fluorescent nature. The compounds can be analysed upto the levels of nanograms (Nahata 2011). Fluorimetry method developed by Ayad MM et al confirms this theory and found to be most sensitive method in this list. The aciddye method can provide a more sensitive technique for certain amines and quaternary ammonium compounds that absorb weakly in the ultraviolet region (Shrivastava et al., 2011). There are eight different methods based on acid-dye method (Aydoğmuş 2009, El Sheikh 2012, Ammar 2014).

The differentiation of atomic spectra has considerable advantages for spectrophotometry in the UV and VIS regions. It is the key for the potential enhancement of resolution of overlapping bands, it facilitates the detection poorly absorbed peaks arising from admixtures or impurities in solution or for structural reasons and it enables the exact determination of $\lambda_{\max }$ of the particular analyte species and increases the sensitivity of spectrophotometric procedures In addition, it is an excellent background elimination technique (Sommer, 1989). Only one first derivative spectrophotometry method for the determination of doxazosin was found (Bebawy et al., 2002). One negative method of simultaneous determination of doxazosin with prazosin, terazosin, tamsulosin and alfuzosin (Shrivastava \& Gupta 2011) is also available. The summary of all of the spectrophotometry methods are provided under Table 1. 
Table 1: Spectrophotometric Methods for the Determination of Doxazosin

\begin{tabular}{|c|c|c|c|c|c|c|}
\hline Principle & Wavelength & $\begin{array}{l}\text { Linearity } \\
\text { range }\end{array}$ & LOD & LOQ & Application & Ref \\
\hline $\begin{array}{l}\text { Acetylacetone together with formaldehyde } \\
\text { react with primary amines by Hantzsch reac- } \\
\text { tion forming a yellow product } \\
\text { (dihydrolutidine derivatives) measured } \\
\text { spectrophotometrically and } \\
\text { spectrofluorimetrically }\end{array}$ & $\begin{array}{l}336 \mathrm{~nm}, \lambda_{\mathrm{ex}}=400 \\
\text { and } \lambda_{\mathrm{em}}=475 \mathrm{~nm}\end{array}$ & $\begin{array}{l}8-36 \mu \mathrm{g} / \mathrm{ml} \\
0.02-0.22 \\
\mu \mathrm{g} / \mathrm{ml}\end{array}$ & $\begin{array}{l}0.693 \mu \mathrm{g} / \mathrm{ml} \\
0.01 \mu \mathrm{g} / \mathrm{ml}\end{array}$ & $\begin{array}{l}2.289 \mu \mathrm{g} / \mathrm{ml} \\
0.02 \mu \mathrm{g} / \mathrm{ml}\end{array}$ & $\begin{array}{l}\text { Pure and } \\
\text { tablets }\end{array}$ & $\begin{array}{l}\text { Ayad et al., } \\
2012,\end{array}$ \\
\hline $\begin{array}{l}\text { Ion-pair complex with Eosin Y reagent } \\
\text { in acetate buffer at pH } 3 \text { measured } \\
\text { spectrophotometrically and } \\
\text { spectrofluorimetrically }\end{array}$ & $\begin{array}{l}547 \mathrm{~nm}, \lambda_{\mathrm{ex}}=340 \\
\text { and } \lambda_{\mathrm{em}}=570 \mathrm{~nm}\end{array}$ & $\begin{array}{l}2-14 \mu \mathrm{g} / \mathrm{ml} \\
1-10 \mu \mathrm{g} / \mathrm{ml}\end{array}$ & $\begin{array}{l}0.393 \mu \mathrm{g} / \mathrm{ml} \\
0.0784 \mu \mathrm{g} / \mathrm{ml}\end{array}$ & $\begin{array}{l}1.191 \mu \mathrm{g} / \mathrm{ml} \\
0.241 \mu \mathrm{g} / \mathrm{ml}\end{array}$ & Tablets & $\begin{array}{l}\text { Ammar et } \\
\text { al., } 2014\end{array}$ \\
\hline $\begin{array}{l}\text { Simple spectrophotometric assay by dissolv- } \\
\text { ing drug in water }\end{array}$ & $330 \mathrm{~nm}$ & $\begin{array}{l}1.0 \times 10^{-5} \\
\text { and } \\
5.0 \times 10^{-5} \mathrm{M}\end{array}$ & - & $1 \times 10^{-5} \mathrm{M}$ & $\begin{array}{l}\text { Compared } \\
\text { with volta- } \\
\text { metric meth- } \\
\text { od }\end{array}$ & $\begin{array}{l}\text { Altiokka } \\
2001\end{array}$ \\
\hline $\begin{array}{l}\text { Stability indicating first derivative spectropho- } \\
\text { tometry }\end{array}$ & $256 \mathrm{~nm}$ & $\begin{array}{l}8-120 \\
\mu \mathrm{g} / \mathrm{ml} \\
1.0-12,1.0-\end{array}$ & - & $0.8 \mathrm{~g} / \mathrm{ml}$ & $\begin{array}{l}\text { Bulk and } \\
\text { tablets }\end{array}$ & $\begin{array}{l}\text { Bebawy et } \\
\text { al., } 2002\end{array}$ \\
\hline $\begin{array}{l}\text { Ion pair complex with dyes bromocresol } \\
\text { green, bromothymol blue, methyl orange and } \\
\text { alizarine red in acidic buffer pH 3.0-5.0. }\end{array}$ & $\begin{array}{l}418,414,425 \text {, and } \\
426 \mathrm{~nm}\end{array}$ & $\begin{array}{l}16,1.0-12 \\
4.0-50 \\
\mu \mathrm{g} / \mathrm{ml}\end{array}$ & $\begin{array}{l}0.275,0.296 \\
0.164,0.672 \\
\mu \mathrm{g} \mathrm{ml}^{-1}\end{array}$ & $\begin{array}{l}0.915,0.988 \\
0.547,2.24 \mu \mathrm{g} \\
\mathrm{ml}^{-1}\end{array}$ & $\begin{array}{l}\text { Pure and } \\
\text { tablets }\end{array}$ & $\begin{array}{l}\text { El Sheikh } \\
\text { et al., } 2012\end{array}$ \\
\hline $\begin{array}{l}\text { Ion-pair complexes with the acidic } \\
\text { sulfophthalein dyes bromocresol purple (BCP) } \\
\text { and bromophenol blue (BPB) in pH } 3.3 \text { and } \\
4.5 \text { citrate-phosphate buffer }\end{array}$ & $\begin{array}{l}403 \text { and } 410 \mathrm{~nm} \\
\text { for BCP and BPB, } \\
\text { respectively }\end{array}$ & $\begin{array}{l}3-18 \mu \mathrm{g} / \mathrm{ml} \\
3-20 \mu \mathrm{g} / \mathrm{ml}\end{array}$ & $\begin{array}{l}0.314 \text { and } \\
0.408 \mathrm{mcg} / \mathrm{ml} \\
\text { respectively }\end{array}$ & $\begin{array}{l}1.045 \text { and } \\
1.360 \mathrm{mcg} / \mathrm{ml} \\
\text { respectively }\end{array}$ & Tablets & \\
\hline $\begin{array}{l}\text { Charge transfer reaction of the drug as an n- } \\
\text { electron donor with either 2,3-dichloro-5,6- } \\
\text { dicyano-1,4-benzoquinone (DDQ) or 7,7,8,8- } \\
\text { tetracyanoquinodimethane (TCNQ) as pi- } \\
\text { acceptors, to give colored radical anions }\end{array}$ & $\begin{array}{l}457 \mathrm{~nm} \text { in acetoni- } \\
\text { trile and } 838 \mathrm{~nm} \text { in } \\
\text { methanol for DDQ } \\
\text { and TCNQ, respec- } \\
\text { tively }\end{array}$ & $\begin{array}{l}15-95 \\
\mu \mathrm{g} / \mathrm{ml}, 10- \\
100 \mu \mathrm{g} / \mathrm{ml}\end{array}$ & $\begin{array}{l}1.935 \text { and } \\
1.610 \mathrm{mcg} / \mathrm{ml} \\
\text { respectively }\end{array}$ & $\begin{array}{l}6.449 \text { and } \\
5.367 \mathrm{mcg} / \mathrm{ml} \\
\text { respectively }\end{array}$ & Tablets & $\begin{array}{l}\text { Aydoğmuş } \\
\text { et al., } 2009\end{array}$ \\
\hline
\end{tabular}

\subsection{Chromatographic methods}

High-performance liquid chromatography (HPLC) was introduced to pharmaceutical analysis not long after its discovery in the late 1960s. By now it has developed into a generally applicable analytical method providing rapid and versatile separation possibilities that meet the increasing requirements for purity testing of bulk pharmaceuticals and pharmaceutical products (Shrivastava \& Gupta 2012). Ten different HPLC determinations with UV detectors (Eu Ph 2007, Dhanya et al., 2011, Kulsum et al., 2011, Shrivastava \& Gupta 2012, Naidu et al., 2012, Rao et al., 2012, Rao et al., 2012, Sreevatsav et al., 2013, Shrivastava \& Gupta 2014,) were found in available literature out of which three are based on gradient elution (Eu Ph 2007, Shrivastava \& Gupta, 2012 , Shrivastava \& Gupta 2012). Detectors that measure absorption of light in the ultraviolet (UV) or visible (VIS) regions were used for at least $75 \%$ of the applications during the first decade of high performance liquid chromatography (Vickrey 1983). The UV-Vis absorbance detector monitors the absorption of UV or visible light in the HPLC eluent. They are the most common detectors since most analytes of interest (e.g. Pharmaceuticals) have UV absorbance (Papadoyannis 1990). The main disadvantage of these detectors - either fixed wavelength detectors or variable wavelength- is that they do not detect aliphatic components in the samples of clinical interest (Dong 2006).

Gradient elution gave a shorter overall analysis with similar resolution of the critical pair compared to isocratic elution without sacrificing repeatability in retention time, peak area and peak height or linearity of the calibration curve (Karch 2008). In this review three gradient elution methods (Eu $\mathrm{Ph} 2007$, Shrivastava \& Gupta, 2012, Shrivastava \& Gupta 2012) are also included.

Fluorescence detectors, with variable excitation and emission wavelengths, provide high sensitivity and specificity for the detection and quantification of fluorescence compounds, but they are more useful for quantification rather than identification (Schellinger \& Carr 2006). There are some reported disadvantages such as decrease in the yield of fluorenscence by quenching and reabsorption of reemitted light. Also fluoroscense intensity may also be affected by the column temperature in gradient chromatography, since chromatography efficiency is strongly dependent on solvent composition. Despite all of these disadvantages, fluorescence detection is still one of the most valuable technique for the trace analysis by HPLC (Swadesh 2001). During the preparation of this review seven (Bhavesh et al., 2002, Sripalakit et al., 2005, Sripalakit et al., 2006, Wongsinsup et al., 2007, Kwon et al., 2007, Kaewvichit et al., 2007) different HPLC methods with fluorescence detection were found.

Hydrophilic interaction liquid chromatography (HILIC), although not a new technique, has enjoyed a recent renaissance with the introduction of robust and reproducible stationary phases (Cubbon 2010). HILIC can provide better chromatographic retention of highly polar or ionizable analytes, can separate analytes of widely differing polarity in a reasonable time, can enhance sensitivity with electrospray LC-MS, and can resolve an analyte and its counter-ion in the same analysis (Zhang 2012). HILIC-MS/MS method for the quantitation of doxazosin is developed and validated by $\mathrm{Ji}$ et al 2008. This method was claimed to be free from matrix effects assessed by post extraction analyte spiking.

The combination of chromatography and mass spectrometry is a subject that has attracted much of interest over the large forty years or so. But the complexity of mass spectrometer has meant that the majority of chromatographers has not had direct access to the instrumentation and has had to rely on service providers. Therefore they are unable to react rapidly to the result of analysis and consequently particularly inconvenient detector to contemplate using. However the combination of HPLC with mass spectrometry allows more definitive identification and the quantitative determination of compounds that are not fully resolved chromatographically (Ardrey 2003). Two LC-MS methods (Chytil et al., 2010, Erceg et al., 2010) were also found for the determination of doxazosin. Both the methods have appreciable sensitivity and may be used in biological matrices.

UPLC has been gradually adopted in industrial labs, especially the pharmaceutical industry due to its high resolution, high speed, and solvent saving since its introduction in early 2004. A UPLC method using a sub- $2 \mu \mathrm{m}$ column could reduce the analysis time by upto $80 \%$ compared with the HPLC method using conventional $3.5 \mu \mathrm{m}$ column without sacrificing separation performance. In addition, much shorter run time significantly reduces UHPLC method development scouting time (Chen \& Kord 2013). In this review only one such method (Al-Dirbashi et al., 2011) was found. 
The modern HPTLC technique, combined with automated sample application and densitometric scanning, is sensitive and completely reliable, suitable for use in qualitative and quantitative analysis. HPTLC is a valuable tool for reliable identification because it can provide chromatographic fingerprints that can be visualized and stored as electronic images (Srivastava 2011). Advantages of HPTLC over TLC include more rapid separation, better resolution and more sensitive detection (5 - 10 fold), without the need for prior extraction (Andol \& Purohit 2010). HPTLC produces visible chromatograms complex information about the entire sample is available at a glance. Multiple samples are seen simultaneously, so that reference and test samples can be compared for identification (Shepherd et al., 1978). Three HPTLC methods (Shepherd et al., 1978, Altiokka 2001, Sreevatsav 2013) for the determination of doxazosin were found. One of these methods is stability indicating method (Bebawy 2002).

The summary of all of the chromatographic methods are presented under Table 2. HPLC-UV method (Kuslum et al., 2011) is the most sensitive method developed by using UV detector. With LOD of $0.1 \mathrm{ng} / \mathrm{ml}$ method (Bhavesh et al., 2002) is the most sensitive method in the category of fluorescence detectors. Inspite of many advantages of LC-MS/MS equipments, methods available in literature does not seem to produce any significant advantage in terms of sensitivity. Overall HPLC methods developed by using fluorescence detectors have good sensitivity. UPLC-MS/MS method (Al-Dirbashi et al., 2006) is the most sensitive method in all of the methods developed for the determination of doxazosin in different matrices. Advantages of such methods are already discussed in above texts.

Table 2: Chromatographic methods for the determination of doxazosin in different matrices

\begin{tabular}{|c|c|c|c|c|c|c|c|c|}
\hline Method & $\begin{array}{l}\text { Chromatographic } \\
\text { Conditions } \\
\end{array}$ & Mobile Phase & $\begin{array}{l}\text { Linear } \\
\text { Range }\end{array}$ & Detection & LOD & LOQ & Application & Reference \\
\hline HPLC-UV & $\begin{array}{l}\text { Column } 3.9 \mathrm{~mm} \text { in } \\
\text { inside diameter } \\
\text { and } 15 \mathrm{~cm} \text { in length, } \\
\text { packed with } \\
\text { octadecylsilanized } \\
\text { silica gel } \\
\text { for liquid chromatog- } \\
\text { raphy }(4 \mu \mathrm{m} \text { in parti- } \\
\text { cle diameter). Tem- } \\
\text { perature } 25^{\circ} \mathrm{C}\end{array}$ & $\begin{array}{l}\text { A mixture of } 0.05 \mathrm{~mol} / \mathrm{L} \text { potassi- } \\
\text { um dihydrogen phosphate } \mathrm{TS}, \mathrm{pH} \\
3.0 \text {, methanol and acetonitrile } \\
(12: 8: 3) \text {. }\end{array}$ & NM & $246 \mathrm{~nm}$ & NM & NM & Pure & JP 2007 \\
\hline $\begin{array}{l}\text { Gradient } \\
\text { HPLC-UV }\end{array}$ & $\begin{array}{l}\text { Base activated } \\
\text { octylsilyl silica gel } \\
\text { column } 250 \times 4.0 \mathrm{~mm} \text {, } \\
5 \mu \mathrm{m}\end{array}$ & $\begin{array}{l}10 \mathrm{~g} / 1 \mathrm{H}_{3} \mathrm{PO}_{4} \text { and } 10 \mathrm{~g} / \mathrm{l} \text { solution } \\
\text { of phosphoric acid in ACN. Temp } \\
35^{\circ} \mathrm{C}\end{array}$ & NM & $210 \mathrm{~nm}$ & - & $\begin{array}{l}\text { Assay and } \\
\text { related } \\
\text { substance }\end{array}$ & $\begin{array}{l}\text { Assay and related } \\
\text { substance }\end{array}$ & Eu Ph 2007 \\
\hline $\begin{array}{l}\text { RP-HPLC- } \\
\text { UV }\end{array}$ & $\begin{array}{l}\text { Chromolith RP-C } \mathrm{C}_{18} \\
\text { column }\end{array}$ & $\begin{array}{l}\text { Mixture of potassium phosphate } \\
\text { buffer and methanol (40:60 v/v) }\end{array}$ & $\begin{array}{l}1-5 \\
\mu \mathrm{g} / \mathrm{ml}\end{array}$ & $251 \mathrm{~nm}$. & $0.1 \mu \mathrm{g}$ & $0.5 \mu \mathrm{g}$ & Tablets & Dhanya 2011 \\
\hline HPLC-UV & $\begin{array}{l}\text { Chromolith RP-C18 } \\
\text { column, } 100 \mathrm{~mm} \times 10 \\
\mu\end{array}$ & $\begin{array}{l}\text { Mixture of Methanol and Potas- } \\
\text { sium Dihydrogen Orthophosphate } \\
\text { in the proportion } 60: 40 \text {. And } \\
\text { adjust the pH to } 5.0 \pm 0.05 \text { with } \\
\text { sodium hydroxide solution. }\end{array}$ & $\begin{array}{l}50-150 \\
\mu \mathrm{g} / \mathrm{ml}\end{array}$ & $251 \mathrm{~nm}$ & NM & NM & $\begin{array}{l}\text { Pharmaceutical } \\
\text { Preparations }\end{array}$ & $\begin{array}{l}\text { Naidu et al., } \\
2012\end{array}$ \\
\hline HPLC-UV & $\begin{array}{l}\text { X Terra } ® \mathrm{RP} 18,5 \\
\text { um column having } \\
250 \times 4.6 \mathrm{~mm} \text { internal } \\
\text { diameter }\end{array}$ & $\begin{array}{l}\text { ortho phosphoric acid: Acetoni- } \\
\text { trile }(60: 40 \mathrm{v} / \mathrm{v}) \text { and adjust the } \mathrm{pH} \\
\text { to } 3.2 \text { by using } 0.03 \mathrm{M} \text { potassium } \\
\text { hydrogen phosphate buffer. }\end{array}$ & $\begin{array}{l}48-144 \\
\mu \mathrm{g} / \mathrm{ml}\end{array}$ & $245 \mathrm{~nm}$ & $\begin{array}{l}0.06 \\
\mu \mathrm{g} / \mathrm{ml}\end{array}$ & $0.08 \mu \mathrm{g} / \mathrm{ml}$ & $\begin{array}{l}\text { Bulk and Pharma- } \\
\text { ceutical Prepara- } \\
\text { tion }\end{array}$ & $\begin{array}{l}\text { Kulsum et al., } \\
2011\end{array}$ \\
\hline HPLC-UV & $\begin{array}{l}\text { LiChroCART- } \\
\text { Lichrosphere } 100, \\
\text { C18, RP column } \\
(250 \mathrm{~mm} \times 4 \mathrm{~mm} \times \\
5 \mu \mathrm{m}) \text { maintained at } \\
\text { ambient temperature, } \\
\text { eluted with mobile } \\
\text { phase at a flow rate of } \\
1 \mathrm{ml} / \mathrm{min} \text { for } 10 \mathrm{~min} .\end{array}$ & Methanol-water $(60: 40 \% \mathrm{v} / \mathrm{v})$ & $\begin{array}{l}1-300 \\
\mu \mathrm{g} / \mathrm{ml}\end{array}$ & $247 \mathrm{~nm}$ & $\begin{array}{l}0.3 \\
\mu \mathrm{g} / \mathrm{ml}\end{array}$ & $1.2 \mu \mathrm{g} / \mathrm{ml}$ & $\begin{array}{l}\text { Pharmaceutical } \\
\text { formulations. }\end{array}$ & $\begin{array}{l}\text { Rao et al., } \\
2012\end{array}$ \\
\hline HPLC-UV & $\begin{array}{l}\text { Chromosil } \mathrm{C}_{18}(250 \\
\left.\mathrm{mm} \mathrm{m}^{\prime} 4.6 \mathrm{~mm}, 5 \mu \mathrm{m}\right) \\
\text { column at } \\
\text { ambient temperature } \\
\text { A Chromolith RP-18 }\end{array}$ & $\begin{array}{l}\text { Methanol:water:acetonitrile } \\
(25: 25: 50 \mathrm{v} / \mathrm{v})\end{array}$ & $\begin{array}{l}0.5-2.5 \\
\mathrm{mg} / \mathrm{ml}\end{array}$ & $280 \mathrm{~nm}$ & $\begin{array}{l}40 \\
\mu \mathrm{g} / \mathrm{ml}\end{array}$ & $110 \mu \mathrm{g} / \mathrm{ml}$ & $\begin{array}{l}\text { Human plasma and } \\
\text { pharmaceutical } \\
\text { formulations }\end{array}$ & $\begin{array}{l}\text { Rao et al., } \\
2012\end{array}$ \\
\hline $\begin{array}{l}\text { HPLC-UV } \\
\text { Gradient }\end{array}$ & $\begin{array}{l}\text { Kromasil C18 column } \\
(250 \times 4.6 \mathrm{~mm}, 5.0 \\
\mu \mathrm{m})\end{array}$ & $\begin{array}{l}\text { The gradient condition of the } \\
\text { mobile phase (A:B:C:D) was: } \\
\text { 60:40:0:0 for } 8 \text { min, } 60: 20: 20: 0 \\
\text { for } 1 \mathrm{~min}, 60: 0: 40: 0 \text { for } 12 \mathrm{~min} \text {, } \\
40: 20: 20: 20 \text { for } 1 \mathrm{~min}, 30: 30: 0: 40 \\
\text { for } 6 \text { min, } 50: 50: 0: 0 \text { for } 1 \mathrm{~min} \text {, } \\
\text { and further } 60: 40: 0: 0 \text { for } 1 \mathrm{~min} \text { for } \\
\text { system equilibration. }\end{array}$ & $\begin{array}{l}4-16 \\
\mu \mathrm{g} / \mathrm{ml}\end{array}$ & $230 \mathrm{~nm}$ & $\begin{array}{l}0.14 \\
\mu \mathrm{g} / \mathrm{ml}\end{array}$ & $\begin{array}{l}0.462 \\
\mu \mathrm{g} / \mathrm{ml}\end{array}$ & Tablets & $\begin{array}{l}\text { Shrivastava \& } \\
\text { Gupta } 2012\end{array}$ \\
\hline $\begin{array}{l}\text { HPLC-UV } \\
\text { Gradient }\end{array}$ & $\begin{array}{l}\text { Kromasil C18 column } \\
(250 \times 4.6 \mathrm{~mm}, 5.0 \\
\mu \mathrm{m})\end{array}$ & $\begin{array}{l}\text { A: ACN-diethylamine }(0.05 \mathrm{ml}) \text {, } \\
\text { B: methanol, and C: } 10 \mathrm{mM} \\
\text { Ammonium acetate, }(\mathrm{A}: \mathrm{B}: \mathrm{C}) \text { was: } \\
60: 40: 0: 0 \text { for } 8 \text { min, } 60: 20: 20: 0 \\
\text { for } 1 \mathrm{~min}, 60: 0: 40: 0 \text { for } 5 \text { min, } \\
\text { and a further } 60: 40: 0: 0 \text { gradient } \\
\text { for } 1 \text { min for system equilibration }\end{array}$ & $\begin{array}{l}2-500 \\
\mu \mathrm{g} / \mathrm{ml}\end{array}$ & $254 \mathrm{~nm}$ & $\begin{array}{l}0.109 \\
\mu \mathrm{g} / \mathrm{ml}\end{array}$ & $\begin{array}{l}0.332 \\
\mu \mathrm{g} / \mathrm{ml}\end{array}$ & Tablets & $\begin{array}{l}\text { Shrivastava \& } \\
\text { Gupta } 2012\end{array}$ \\
\hline HPLC-F & $\begin{array}{l}\text { Apollo } \mathrm{C}_{18} \text { column } \\
(250-\times 4.6 \text {-mm i.d., } 5 \\
\mu \mathrm{m}, 250 \mathrm{~A})(\text { Alltech, } \\
\text { Deerfield, IL) fitted } \\
\text { with a refillable guard } \\
\text { cartridge (Alltech) } \\
\text { packed with Apollo } \\
\text { C18 }(7.5 \times 4.6 \text {-mm } \\
\text { i.d., } 5 \mu \mathrm{m}) .\end{array}$ & $\begin{array}{l}\text { The mobile phase was methanol- } \\
\text { acetonitrile- } 0.04 \mathrm{M} \text { disodium } \\
\text { hydrogen orthophosphate } \\
(22: 22: 56 \mathrm{v} / \mathrm{v}) \text { adjusted to } \mathrm{pH} 5 \\
\text { with } 0.9 \mathrm{M} \text { phosphoric acid. All } \\
\text { separations were performed } \\
\text { isocratically at a flow rate of } 1.2 \\
\mathrm{~mL} / \mathrm{min} \text {, and the column tempera- } \\
\text { ture was maintained at room } \\
\text { temperature. }\end{array}$ & $\begin{array}{l}0.5-20 \\
\mathrm{ng} / \mathrm{mL}\end{array}$ & $\begin{array}{l}\lambda_{\mathrm{ex}}=246 \mathrm{~nm} \\
\lambda_{\mathrm{em}}=389 \mathrm{~nm}\end{array}$ & $\begin{array}{l}0.125 \\
\mathrm{ng} / \mathrm{ml}\end{array}$ & $0.5 \mathrm{ng} / \mathrm{ml}$ & Human plasma & $\begin{array}{l}\text { Sripalakit et } \\
\text { al., } 2005\end{array}$ \\
\hline
\end{tabular}




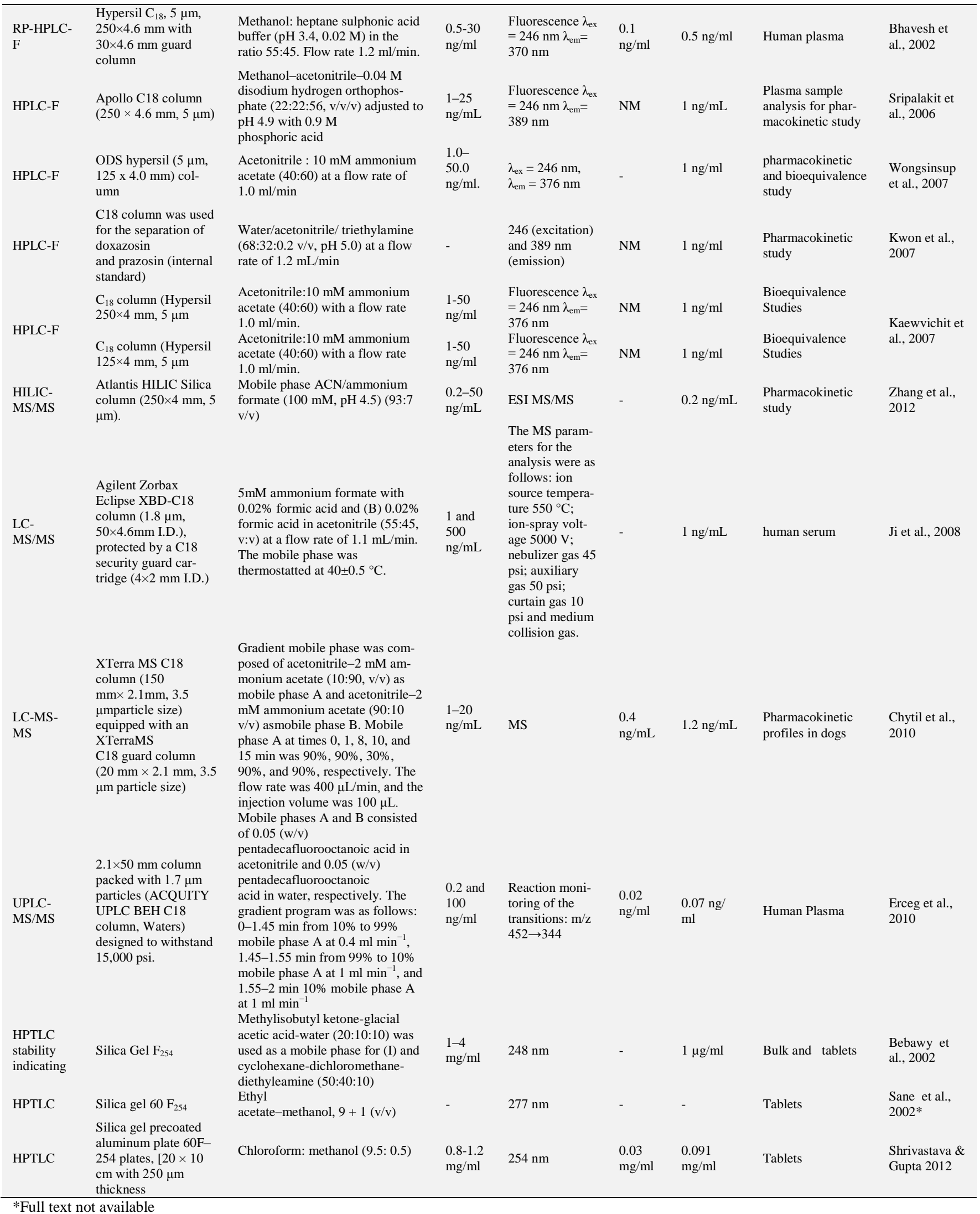

\subsection{Electro analytical methods}

Modern electrochemical methods are now sensitive, selective, rapid and easy techniques applicable to analysis in the pharmaceutical fields, and indeed in most areas of analytical chemistry. They are probably the most versatile of all trace pharmaceutically active compound analysis (Shrivastava 2012, Shrivastava et al., 2013) Electroanalytical techniques can easily be adopted to solve many problems of pharmaceutical interest with a high degree of accura- cy, precision, sensitivity and selectivity, often in a spectacularly reproducible way by employing this approach (Zuman 2006).

Two methods based on the mechanism of oxidation of amine group of the drug is described by Arranz et al. Both the methods based on adsorptive stripping (AdS) of doxazosin at the C8 modified carbon paste electrode (C8-MCPE), before its voltametric determination by using Differential pulse voltammetry (DPV) and Square wave voltammetry (SWV). Limit of detection described were $7.4 \times 10^{-10} \mathrm{~mol} / \mathrm{L}$ and $7.7 \times 10^{-10} \mathrm{~mol} / \mathrm{L}$ for $\mathrm{DPV}$ and $\mathrm{SWV}$ 
methods respectively. Both the methods were utilized for the determination of doxazosin in urine and formulations.

Another voltammetric determination method found was described by Altiokka et al. This method is based on based on the oxidation on the surface of platinum electrode in the stationary and rotating conditions for determining and determine doxazosin in the tablets by differential pulse technique at only rotating condition. Detection limits were calculated to be $2 \times 10^{-6} \mathrm{M}$ and $1.5 \times 10^{-5} \mathrm{M}$ DOX accepting signal-to-noise is equal to 3 , for limiting current and peak current, respectively.

DC polarography and the determination of doxazosin employing superimposed increasing amplitude pulse (SIAP) and superimposed constant amplitude pulse (SCAP) polarographic techniques are described by Altiokka and Tuncel 1998. This method is based on the fact that doxazosin molecule has a quinazoline group this group can be reduced by two electrons on the mercury electrode. Another voltametric technique for the determination of doxazosin is also available (Arranze et al., 1997). They evaluated cathodic adsorptive stripping (AdS) response with respect to $\mathrm{pH}$, accumulation variables and instrumental parameters, using differentialpulse (DPV) and square-wave voltammetry (SWV) as redissolution techniques. When the Tenax-modified carbon paste electrode was used, the limits of detection were $4.35 \times 10^{-11}$ and $5.18 \times 10^{-11} \mathrm{M}$ for AdS-DPV and AdS-SWV, respectively.

\subsection{Cerimetric method}

Quadrivalent cerium is a powerful oxidizing agent in acidic solutions. The normal oxidation potential with reference to hydrogen is 1.96 volts (Rani 2014). The available cerimetric method (Walb 1940) is based on the oxidation of Doxazosin drug by a known excess amount of cerium IV sulphate in acid medium. Unreacted cerium IV sulphate was treated with Iron II sulphate and the remaining Iron III sulphate was treated with (1M) Ammonium thiocyanate to forms blood red colour of Iron III sulphate thiocyanate drug complex solution. This resultant solution was then measured at $505 \mathrm{~nm}$ against reagent blank.

\section{Conclusion}

It is essential to ensure that these analytical methods are fit for their purpose. Method validation is aimed at providing this guarantee (Rozet et al., 2012). This review includes discussion on sensitivity of methods and also highlights on advantages or disadvantages of different types of method. In this way all of the analytical methods for the determination of doxazosin mesylate in different matrices are discussed here. The summary of all of the spectrophotometry methods are presented in Table 1, whereas all chromatographic methods are presented under Table 2 . This review is helpful for researchers and scientists engaged in the development of new analytical method or formulation for doxazosin.

\section{References}

[1] U.S. Department of Health and Human Services. (2006) Prostate Enlargement: Benign Prostatic Hyperplasia. National Institute of Diabetes and Digestive and Kidney Diseases. [Online] Available: http://kidney.niddk.nih.gov/kudiseases/pubs/prostateenlargement/Pros tateEnlargement_508.pdf.

[2] American Cancer Society. (2014) what is prostate cancer? Prostate Cancer: Early Detection. [Online] Available: http://www.cancer.org/cancer/prostatecancer/moreinformation/prostat ecancerearlydetection/prostate-cancer-early-detection-what-isprostate-cancer.

[3] Jon Kindblom. (2013) Role of prolactin in the prostate gland, studies in transgenic mouse models. 2003, Intellecta Docusys. [Online] Available:

http://www.neurophys.gu.se/digitalAssets/1278/1278430_AVHANDL INGSRAM_Jon_Kindblom.pdf.

[4] Schauer I.G. and Rowley D.R., The functional role of reactive stroma in benign prostatic hyperplasia. Differentiation, Volume 82, (2011) 200-210 http://dx.doi.org/10.1016/j.diff.2011.05.007.
[5] Freeman M.R., and Solomon K.R., Cholesterol and benign prostate disease. Differentiation, Volume 82, (2011) 244-252. http://dx.doi.org/10.1016/j.diff.2011.04.005.

[6] Shrivastava A., and Gupta V.B., Various treatment options for benign prostatic hyperplasia: A current update, J Mid-life Health 3, (2012), 10-9. http://dx.doi.org/10.4103/0976-7800.98811.

[7] Bechis S.K., Otsetov A.G., GeR Olumi A.F., Personalized Medicine for Management of Benign Prostatic Hyperplasia., J Urol, 2014, doi: 10.1016/j.juro.2014.01.114 http://dx.doi.org/10.1016/j.juro.2014.01.114

[8] McLaren I.D., Jerde T.J., Bushman W., Role of interleukins, IGF and stem cells in BPH., Differentiation, Volume 82, (2011) 237-243. http://dx.doi.org/10.1016/j.diff.2011.06.001

[9] Yamada S. and Ito Y., $\alpha 1$-Adrenoceptors in the Urinary Tract. Urinary Tract: Handbook of Experimental Pharmacology, K.E. Andersson and M.C. Michel, Ed. Springer Heidelberg Dordrecht London New York, Volume, 202. (2011).

[10] Irani J., Are all alpha-blockers created the same? Eur Urol, Volume 49, (2006), 420-2. http://dx.doi.org/10.1016/j.eururo.2005.12.032.

[11]Shrivastava A., Various Analytical Methods for the determi-nation of Terazosin in different matrices, World Journal of Analytical Chemistry, Volume 1(4), (2013) 80-86.

[12]Takahashi S. and Yamaguchi K., Satoru Sakura Clinical Study Group. Treatment of benign prostatic hyperplasia and aging: Impacts of alpha-1 blockers on sexual function. Journal of Men's Health, Volume 8(Suppl. 1), (2011) S25-S28. http://dx.doi.org/10.1016/S1875-6867 (11)60015-8.

[13]Perabo F.G.E. Drug development for LUTS - The challenge for industry. Drug Discovery Today: Therapeutic Strategies, Volume 9(1), (2012) e5-e14. http://dx.doi.org/10.1016/j.ddstr.2012.02.001.

[14] Shrivastava A., Patel A., Gupta, V.B., Stability Indicating HPTLC Determination of Terazosin in Tablet Formulation. World Journal of Analytical Chemistry, Volume 1(3), (2013) 31-36.

[15] Shrivastava A. and Aggrawal P., Various Analytical Meth-odologies for Determination of Selective $\alpha 1 \mathrm{~A}$ Receptor Blocker Tamsulosin Hydrochloride and its Combinations in different matrices. World Journal of Analytical Chemistry Volume 1(3), (2013) 37-48. doi: 10.12691/wjac-1-3-3.

[16]Ding H., Du W., Hou Z.Z., Wang H.Z., and Wang Z.P., Silo-dosin is effective for treatment of LUTS in men with BPH: a systematic review, Asian Journal of Andrology, Volume 15, (2013) 121-128. http://dx.doi.org/10.1038/aja.2012.102.

[17]A. Shrivastava, Benign Prostatic Hyperplasia: A Review of Different Treatment Options. In Handbook of Clinical Phar-macy. Editors: Fernández-Ginés FD, Nieto-Guindo P. OM-ICS Group eBooks, USA. (2014).

[18] Attia A.K., Abdel-Moety M.M., Abdel-Hamid S.G., Thermal analysis study of antihypertensive drug doxazosin mesilate., Arabian Journal of Chemistry, (2012) http://dx.doi.org/10.1016/j.arabjc.2012.08.006.

[19] Os I and Stokke H.P., Effects of doxazosin in the gastrointes-tinal therapeutic system formulation versus doxazosin standard and placebo in mild-to-moderate hypertension. Doxazosin Investigators' Study Group. Journal of Cardiovascular Pharmacology, Volume 33, (1999) 791-797. http://dx.doi.org/10.1097/00005344-199905000-00017.

[20]Chou C.L., Current Medical Treatment for Benign Prostatic Hyperplasia/Lower Urinary Tract Symptoms. Incontinence \& Pelvic Floor Dysfunction. Volume 1(Suppl 2), (2007), 15-19.

[21]Shorter D., Lindsay J.A., and Kosten T.R., The alpha-1 ad-renergic antagonist doxazosin for treatment of cocaine de-pendence: A pilot study, Drug and Alcohol Dependence, Volume 131(1-2), (2013) 6670. http://dx.doi.org/10.1016/j.drugalcdep.2012.11.021.

[22]Erturhan, S., Bayrak, O., Sarica, K., Seckiner, I., Baturu, M. Sen H. Efficacy of medical expulsive treatment with doxazosin in pediatric patients. Urology, 81(3), (2013), 640-3. doi: 10.1016/j.urology.2012.11.031. http://dx.doi.org/10.1016/j.urology.2012.11.031.

[23]Wilt T.J., and MacDonald R., Doxazosin in the treatment of benign prostatic hypertrophy: an update. Clin Interv Aging., Volume 1(4), (2006) 389-401. http://dx.doi.org/10.2147/ciia.2006.1.4.389.

[24]European Pharmacopoeia. 2007, European Directorate for the Quality of Medicines. Strasbourg.

[25] Thiyagarajan M., $\alpha$-Adrenoceptor antagonists in the treatment of benign prostatic hyperplasia., International Journal of Experimental and Clinical Pharmacology, Volume 65, (2002) 119-128.

[26]Shrivastava A., and Gupta V.B., A Review on Various Ana-lytical Methods on Some Alpha Adrenergic Antagonists. Current Pharmaceutical Analysis, Volume 7, (2011) 27-41. http://dx.doi.org/10.2174/157341211794708695. 
[27]Xu Q.A., and Madden T.L., Analytical Methods for Thera-peutic Drug Monitoring and Toxicology, John Wiley and Sons, New Jersey. (2011). http://dx.doi.org/10.1002/9780470909799.

[28]Humphreys J.E. and Waite M.A., Alpha-1 Blockers. A new generation of antihypertensive agents, Journal of Clinical Pharmacy and Therapeutics, Volume 14, (1989) 263-283. http://dx.doi.org/10.1111/j.13652710.1989.tb00248.x.

[29]Homma Y., Araki I, Igawa Y., Ozono S., Gotoh M., Yamanishi T., Yokoyama O., Yoshida M. and Japanese Soci-ety of Neurogenic Bladder, Clinical guideline for male lower urinary tract symptoms, International Journal of Urology, 16, (2009) 775-790. http://dx.doi.org/10.1111/j.1442-2042.2009.02369.x.

[30]Gurbuz M.C., Polat H., Canat L., Kilic M., and Caskurlu T., Efficacy of Three Different Alpha 1-Adrenergic Blockers and Hyoscine NButylbromide for Distal Ureteral Stones. Inter-national Brazilian Journal of Urology, Volume 37, (2011) 195-202.

[31]Chandran S., and Singh, R.S., Comparison of various interna-tional guidelines for analytical method validation. Pharmazie, 62, (2007) 414.

[32]Shrivastava A., and Gupta V.B., Methods for the determina-tion of limit of detection and limit of quantitation of the ana-lytical methods, Chron Young Sci Volume 2, (2011) 21-5. http://dx.doi.org/10.4103/2229-5186.79345.

[33]Araujo P., Key aspects of analytical method validation and linearity evaluation. Journal of Chromatography B Analytical Technology Biomedical Life Sciences, Volume 877, (2009) 2224-34.

[34]Kumar A., Kishore L., Kaur N., and Nair A., Method devel-opmen and validation: Skills and tricks. Chron Young Sci., Volume 3, (2012) 3-11. http://dx.doi.org/10.4103/2229-5186.94303.

[35] Shrivastava A., and Saxena P., Validation of Analytical Methods: Methodology and Statistics. Ist edition, CBS Publi-cations, New Delhi. (2014).

[36]Marczenko Z., Balcerzak M., Separation, Preconcentration and Spectrophotometry in Inorganic Analysis. Elsevier Science Publishers, Netherlands. (2000).

[37]Ayad M.M., Abdellatef H.E., Hosny M.M., Sharaf Y.A., Spectrophotometric and spectrofluorimetric determination of amlodipine besilate and doxazosin mesilate in bulk and in dosage forms via Hantzsch reaction. International Journal of Pharmaceutical and Biomedical Research Volume 3(2), (2012), 111-116.

[38]Ammar R.A., EL-Brashy A.M., AL-Sahly T.N., Spectro-photometric and Spectrofluorometric Determination of Dox-azosin Mesylate in Tablets via Eosin Y, Asian Journal of Chemistry, Volume 26(1), (2014) 57-62.

[39] Nahata A., Spectrofluorimetry as an Analytical tool. Pharm Anal Acta, Volume 2, (2011) 107e. http://dx.doi.org/10.4172/21532435.1000107e.

[40]Shrivastava A., Saxena P., and Gupta V.B., Spectrophoto-metric estimation of tamsulosin hydrochloride by acid-dye method., Pharm Methods, Volume 2, (2011) 53-60. http://dx.doi.org/10.4103/2229 4708.81089.

[41]Altiokka G., Voltammetric determination of doxazosin in tablets using rotating platinum electrode. Journal of Pharma-ceutical and Biomedical Analysis, Volume 25, (2001) 387-391. http://dx.doi.org/10.1016/S0731-7085 (00)00515-X.

[42]Bebawy L.I., Moustafa A.A., Abo-Talib N.F., Stability-indicating methods for the determination of doxazosin mezylate and celecoxib. Journal of Pharmaceutical and Bio-medical Analysis, Volume 27(5), (2002) 779-93. http://dx.doi.org/10.1016/S0731-7085 (01)00523-4.

[43]El Sheikh, R., Esmail, N.S., Gouda, A.A., Basset, W.A., Extractive spectrophotometric determination of some $\alpha$-adrenergic antagonists in pure forms and in pharmaceutical formulations. CI \& CEQ, Volume 18(2), (2012) 179-191. http://dx.doi.org/10.2298/CICEQ110917060E.

[44]Aydoğmuş Z., Barla A., Spectrophotometric determination of doxazosin mesylate in tablets by ion-pair and charge-transfer complexation reactions, Journal of AOAC International, 92(1), (2009) $131-7$.

[45]Sommer L., Analytical absorption spectrophotometry in the visible and ultraviolet, the principles. Elsevier Science Pub-lishers, Netherlands. (1989).

[46]Shrivastava A. and Gupta V.B. Ultra violet spectrophotomet-ric method: Not possible for the simultaneous estimation of alpha one adrenoreceptor blockers. Journal of Pharmaceutical Negative Results, Volume 2, (2011) 115-20. http://dx.doi.org/10.4103/0976-9234.90226.

[47]Shrivastava A. and Gupta V.B., HPLC: Isocratic or Gradient Elution and Assessment of Linearity in Analytical Methods, Journal of Advanced Scientific Research, Volume 3(2), (2012) 12-20.

[48]The Japanese Pharmacopoeia. Vth Edition. Second Supple-ment. The Ministry of Health, Labour and Welfare, 2007.
[49]Dhanya B., Suganthi A., Sen A.K., Sahoo U., and Seth A.K., Determination of Doxazosin Mesylate in Tablets by RP-HPLC., Indian Journal of Pharmaceutical Science, Volume 73(1), (2011) 115-120. http://dx.doi.org/10.4103/0250-474X.89772.

[50]Naidu N.V.S., Reddy M.R.M., and Suguna, P., Development and Validation of the HPLC Method for the Analysis of Doxazosin in Bulk Drug and Pharmaceutical Dosage Forms. International Journal of Pharmaceutical Science and Research 3(8), (2012) 2705-2711.

[51] Kulsum S., Vidya Sagar G., Padmalatha M., Sudheer P., and Bavandla S., Validated RP-HPLC method for the quantitation of doxazocin mesylate in bulk and pharmaceutical dosage forms. Asian Journal of Pharmaceutical Sciences and Clinical Research, Volume Volume 1(1) (2011) 1-5.

[52]Rao K.S., Deb K.B., Rao M.E.B., Patro S.S., and Patnaik A.K., Development and Validation of Stability Indicating Analytical Method for Doxazosin Mesylate and its Application to Kinetic Studies. Chemical Sciences Journal, Volume 3, (2012) 1-10.

[53]Basaveswara Rao, M.V., Prasanthi, V., Sivanadh, M., and Venkata Rao, G., Newer RP-HPLC method for the determi-nation of doxazosin in human plasma and formulation. Bulletin of Pharmaceutical Research, Volume 2(1), (2012) 1-4.

[54] Sreevatsav, S.K., Sunder. S.K, Maleraju, J., Racha, H., Ana-lytica method development and validation of doxazosin me-sylate uncoated tablets by RP-HPLC. International Journal of Biomedical Research, Volume 4(9), (2013) 465-476.

[55] Shrivastava A., and Gupta V.B., Validated HPLC and HPTLC Methods for Simultaneous Determination of Some $\alpha 1$-Adrenoreceptor Blockers. Latin American Journal of Pharmacy, Volume 31 (2), (2012) 279-86.

[56]Shrivastava A., and Gupta V.B., Stability-Indicating RP-HPLC Method for the Simultaneous Determination of Prazosin, Terazosin, and Doxazosin in Pharmaceutical For-mulations., Scientia Pharmaceutica, Volume 80, (2012) 619-631. http://dx.doi.org/10.3797/scipharm.1204-15.

[57] Vickrey T.M., Liquid Chromatography Detectors. Marcel Dekkar Inc, Newyork, Volume 23. (1983)

[58] Papadoyannis I.N., HPLC in clinical chemistry. Marcel Dek-kar. (1990)

[59]Dong M.W., Modern HPLC for Practicing Scientists. John Wiley and Sons, Inc Publications. (2006) http://dx.doi.org/10.1002/0471973106.

[60]Karch S.B., Postmortem Toxicology of Abused Drugs. CRC Press, USA. (2008)

[61] Schellinger A.P., and Carr P.W., Isocratic and gradient elution chromatography: a comparison in terms of speed, retention reproducibility and quantitation, Journal of Chromatography A., Volume 1109(2), (2006) 253-66. http://dx.doi.org/10.1016/j.chroma.2006.01.047.

[62] Swadesh J.K., HPLC: Practical and Industrial Applications, 2nd Edition. CRC Press, USA. (2001)

[63] Sripalakit P., Nermhom P., and Saraphanchotiwitthaya A., Improvement of Doxazosin Determination in Human Plasma Using HighPerformance Liquid Chromatography with Fluo-rescence Detection, Journal of Chromatographic Science, Volume 43, (2005) 63-66. http://dx.doi.org/10.1093/chromsci/43.2.63.

[64]Bhavesh D., Pinal S., Saroj V., and Prakash, S., Determina-tion of doxazosin in human plasma by reverse phase high performance liquid chromatography with fluorescence detector, Indian Journal of Pharmaceutical Sciences, Volume 64(4), (2002) 354-356

[65] Sripalakit P., Nermhom P., and Saraphanchotiwitthaya A., Validation and pharmacokinetic application of a method for determination of doxazosin in human plasma by high-performance liquid chromatography. Biomedical Chromatog-raphy, Volume 20(8), (2006) 729-35. http://dx.doi.org/10.1002/bmc.588.

[66]Wongsinsup C., Taesotikul W., Kaewvichit S., Sangsrijan S., and Sangsrijan S., Simple Method of Extraction and Deter-mination of Doxazosin Mesylate in Human Plasma by High - Performance Liquid Chromatography with Fluorescence De-tector. CMU. Journal of Natural Science, Volume 6(2), (2007) 231-240.

[67]Kwon Y.H., Gwak H.S., Yoon S.J., and Chun I.K., Pharma-cokinetics of Doxazosin Gastrointestinal Therapeutic System after Multiple Administration in Korean Healthy Volunteers., Drug Development and Industrial Pharmacy, Volume 33(8), (2007) 824-829. http://dx.doi.org/10.1080/03639040601012999.

[68] Kaewvichit S., Thongsawat S., Taesotikul W., Wongsinsup C., and Yotsawimonwat S., Duangrat, C., et al., Bioequivalence study of doxazosin tablets in healthy thai male volunteers. Thai Journal of Pharmacology, Volume 29(2), (2007) 19-24.

[69]Cubbon S., Antonio C., Wilson J., and Thomas-Oates J., Metabolomic applications of HILIC-LC-MS. Mass Spec-trometry Reviews, Volume 29(5), (2010) 671-84. http://dx.doi.org/10.1002/mas.20252. 
[70]Zhang W., Han F., Zhao H., Lin Z.J., Huang, Q.M., and Weng, N., Determination of metformin in rat plasma by HILIC-MS/MS combined with Tecan automation and direct injection. Biomedical Chromatography, Volume 26(10), (2012) 1163-9. http://dx.doi.org/10.1002/bmc.2673.

[71]Ji H.Y., Park E.J., Lee K.C., Lee H.S., Quantification of dox-azosin in human plasma using hydrophilic interaction liquid chromatography with tandem mass spectrometry. Journal of Separation Science, Volume 31(9), (2008) 1628-33. doi: 10.1002/jssc.200700662. http://dx.doi.org/10.1002/jssc.200700662.

[72]Ardrey R.E., Liquid Chromatography - Mass Spectrometry: An Introduction. John Wiley and Sons, England, (2003) http://dx.doi.org/10.1002/0470867299.

[73]Chytil L., Strauch B., Cvačka J., Marešová V., Widimský J., Jr, Holaj $\mathrm{R}$ et al., Determination of doxazosin and verapamil in human serum by fast LC-MS/MS: Application to document non-compliance of patients. Journal of Chromatography B, 878, (2010) 3167-3173. http://dx.doi.org/10.1016/j.jchromb.2010.09.032.

[74]Erceg M., Cindric M., Frketic L.P., Vertzoni M., Cetina-Cižmek B., Reppas C., A LC-MS-MS Method for Determi-nation of Low Doxazosin Concentrations in Plasma after Oral Administration to Dogs, Journal of Chromatography Science, Volume 48, (2010) 114 119. http://dx.doi.org/10.1093/chromsci/48.2.114.

[75]Chen S., and Kord A., UPLC method development. Editor: Q. Alan $\mathrm{Xu}$. First Edition, In Ultra-High Performance Liquid Chromatography and its Applications, John Wiley and Sons, Inc. (2013)http://dx.doi.org/10.1002/9781118533956.ch1.

[76]Al-Dirbashi O.Y., Aboul-Enein H.Y., Jacob M., Al-Qahtani K., and Rashed M.S., UPLC-MS/MS determination of dox-azosine in human plasma. Analytical and Bioanalytical Chemistry, 385, (2006) 14391443. http://dx.doi.org/10.1007/s00216-006-0553-8.

[77]Srivastava MM. HPTLC, Springer. (2011).

[78]Andol H.C., and Purohit V.K., High Performance Thin Layer Chromatography (HPTLC): A Modern Analytical tool for Biological Analysis. Nature and Science, Volume 8(10), (2010), 58-61.

[79]Shepherd R.W., Bunting P.S., Khan M., Hill J.G., Soldin S.J., Gall D.G., A rapid, sensitive method for accurate analysis of individual bile acids in biological fluids by high performance thin-layer chromatography and densitometry., Clinical Bio-chemistry, Volume 11(3), (1978) 106-11. http://dx.doi.org/10.1016/S0009-9120 (78)90112-1.

[80]Sane R.T., Francis M., Hijli P.S., Pawar S., Arvind R.P. Determination of doxazosin in its pharmaceutical formulation by highperformance thin-layer chromatography. Journal of Planar Chromatography 15, (2002) 34-7. http://dx.doi.org/10.1556/JPC.15.2002.1.6.

[81] Shrivastava A., Analytical methods for venlaflaxine hydro-chloride and metabolites determinations in different matrices. Systemic Reviews in Pharmacy, Volume 3, (2012), 42-50. http://dx.doi.org/10.4103/0975-8453.107141.

[82] Shrivastava A., Sharma J., and Soni V., Various electroana-lytical methods for the determination of uranium in different matrices, Bulletin of Faculty of Pharmacy, Cairo University., 51(1), (2013) 113-129. http://dx.doi.org/10.1016/j.bfopcu.2012.09.003.

[83]Zuman P., Principles of applications of polarography and voltammetry in the analysis of drugs. FABAD Journal of Pharmaceutical Science 31, (2006) 97-115.

[84]Arranz A., Moreda J.M., and Arranz J.F., Preconcentration and Voltammetric Determination of the Antihypertensive Doxazosin on a C8 Modified Carbon Paste Electrode. Micro-chimica Acta., Volume 134(1-2), (2000) 69-75. http://dx.doi.org/10.1007/s006040070056.

[85]Altiokka G., and Tuncel M., Pulse polarographic (constant and increasing) determinations doxazosin in pharmaceutical tablets, Journal of Pharmaceutical and Biomedical Analysis, Volume 17, (1998) 169175. http://dx.doi.org/10.1016/S0731-7085 (97)00211-2.

[86] Arranz A., de Betono S.F., Moreda J.M., Cid A., Arranz J.F., Cathodic Stripping Voltammetric Determination of Doxazosin in Urine and Pharmaceutical Tablets Using Carbon Paste Electrodes. Analyst, Volume 122, (1997) 849-854. http://dx.doi.org/10.1039/a701210a.

[87] Rani M.E., Doxazosin dosage form in tablets by Cerimetric method. World J Pharmaceutical Research. Volume 3(2), (2014) 2280-2286.

[88]Walb T.A., and James A.E., Permanganate and cerimetric methods in pharmaceutical assays. A study of the relative merits. Journal of the American Pharmaceutical Association, Volume 29(5), (1940) $221-$ 224. http://dx.doi.org/10.1002/jps.3030290508.

[89]Rozet E., Ziemons E., Marini R.D., Boulange, B., and Hubert P., Validation of analytical methods involved in dissolution assays: Acceptance limits and decision methodologies, Ana-lytica Chimica Acta 751, (2012) 44-51. http://dx.doi.org/10.1016/j.aca.2012.09.017. 